\title{
PENGARUH PEMBELAJARAN DARING MATA \\ PELAJARAN SEJARAH MELALUI MICROSOFT \\ OFFICE 365
}

\author{
Anisatul Aziizah ${ }^{1}$, Tegar Bima Sakti ${ }^{2}$, Andriyanto ${ }^{3}$ \\ Program Studi Pendidikan Sejarah \\ Universitas Veteran Bangun Nusantara Sukoharjo \\ 1 anisatul150698@gmail.com, ${ }^{2}$ tgardiwarno18@gmail.com, \\ andri_rey@yahoo.co.id
}

\begin{abstract}
The purpose of this study is to describe how Microsoft Office 365 applications are used in online learning. This study uses a qualitative approach with a descriptive design. The data collection technique is done by collecting information and pictures. The data obtained were then described descriptively. From this method, the research results show that the use of Microsoft Office 365 in online learning activities is said to be quite effective and efficient. With various features in one application, it makes it easier for teachers to use them, because teachers can deliver teaching materials using various facilities or features provided by the office, not only in text but also in text. video form. In addition, teachers can also monitor the activeness of their students with the chat feature, and can efficiently assign assignments as evaluation materials to determine the level of student understanding. In addition, Office 365 can also be used for video conferencing for face-to-face learning via online. This shows that learning using Microsoft Office 365 has problems in terms of students regarding the problem of the size of the application and different network questions for each student but for questions about the Office 365 features it is good with complete teaching features.
\end{abstract}

Keywords : Applications, Learning, Microsoft, Online

\section{PENDAHULUAN}

Saat ini seluruh dunia sedang dilanda wabah virus Covid-19. Covid-19 banyak membawa dampak baik maupun buruk bagi semua mahkluk hidup dan alam semesta. Segala daya dan upaya sudah dilakukan pemerintah guna memperkecil kasus penularan Covid-19 (Ilmiyah, 2020). Untuk melawan Covid19 pemerintah telah melarang untuk berkerumun, pembatasan sosial (social distancing), menjaga jarak fisik (physical distancing), memakai masker, dan selalu mencuci tangan. Virus Covid-19 telah memberikan dampak dalam berbagai 
sektor yaitu sektor perekonomian, industri, kesehatan, dan juga pendidikan.

Dalam bidang pendidikan dampak tersebut memberi tantangan tersendiri bagi lembaga pendidikan, khususnya sekolah. Kementerian Pendidikan dan Kebudayaan Pemerintah telah memberikan perintah untuk melaksanakan pembelajaran secara daring dan larangan untuk melaksanakan pembelajaran secara tatap muka yang disampaikan dalam Surat Edaran Kemendikbud Nomor 15 Tahun 2020 Tentang Pedoman Penyelenggaraan Belajar Dari Rumah Dalam Masa Darurat Penyebaran Corona Virus Disease (Covid-19). Seluruh elemen pendidikan dituntun untuk dapat melaksanakan pembelajaran secara daring dan menerapkan sistem yang berbeda dari biasanya.

Akibatnya hal tersebut menjadikan tantangan bagi seluruh elemen pendidikan baik sekolah maupun guru untuk menentukan strategi dan media pembelajaran yang tepat untuk pengembangan sistem pembelajaran daring tersebut sehingga dapat mencapai tujuan pembelajaran sebagaimana pembelajaran secara tatap muka langsung. Pembelajaran merupakan proses kompleks dalam diri peserta didik dan terkait dengan berbagai aspek dalam diri maupun luar dirinya. Guru sebagai pemberi fasilitas belajar dituntut memiliki kemampuan dalam memilih dan menerapkan strategi pembelajaran. Dengan kemampuan tersebut guru dapat melaksanakan fungsi pemberi fasilitas dengan baik sehingga peserta didik dapat melakukan aktivitas belajar secara efektif (Kusumaningsih, 2011).

Melihat berbagai fakta tersebut, maka penerapan metode online learning (e-learning) menjadi suatu pilihan terbaik bagi dunia pendidikan. Berbagai institusi pendidikan saat ini mulai memanfaatkan teknologi dan menerapkan sistem pembelajaran daring untuk menunjang aktivitas pembelajaran.

Pembelajaran daring adalah pembelajaran yang mampu mempertemukan mahasiswa dan dosen untuk melaksanakan interaksi pembelajaran dengan bantuan internet (Kuntarto, 2017). Penggunaan teknologi dalam pendidikan merupakan alternatif untuk meningkatkan kualitas dan kuantitas hasil dan proses dalam pembelajaran. Maka guru dan peserta didik dituntut aktif untuk menggunakan teknologi pendidikan dalam proses pembelajaran.

Pembelajaran secara daring merupakan cara baru dalam proses belajar mengajar yang memanfaatkan perangkat elektronik khususnya internet dalam 
penyampaian belajar. Pembelajaran daring, sepenuhnya bergantung pada akses jaringan internet (Ezalia et al., 2020). Pembelajaran daring merupakan bentuk penyampaian pembelajaran konvensional yang dituangkan pada format digital melalui internet. Pembelajaran daring, dianggap menjadi satu-satunya media penyampai materi antara guru dan siswa, dalam masa darurat pandemi (Imania \& Bariah, 2019).

Pembelajaran daring dapat menggunakan video conference (webinar Zoom, Webex), Microsoft Teams, Microsoft Form, Whatsapp maupun aplikasi lainnya. Kemunculan media pembelajaran daring ini sudah lama ada. Akibat pandemi Covid-19 banyak sekolah beralih ke pembelajaran jarak jauh dan pemanfaatan berbagai media pembelajaran daring ini mulai merebak di Indonesia. Salah satunya adalah sekolah SMK Muhammadiyah 1 Sukoharjo yang saat ini juga menggunakan sistem pembelajaran daring. Di SMK Muhammadiyah 1 Sukoharjo media yang digunakan untuk pembelajaran daring adalah Microsoft Office 365. Dalam artikel ini akan membahas salah media Microsoft Office 365. Dan munculah rumusan masalah: Bagaimana pengaruh aplikasi Microsoft Office 365 dalam pembelajaran sejarah di kelas X RPL1 SMK Muhammadiyah 1 Sukoharjo?

\section{KAJIAN TEORITIS}

Microsoft Office 365 merupakan kolaborasi berbagai piranti lunak yaitu Microsoft Office, Microsoft Share Point Online, Microsoft Exchange Online dan Microsoft Lync Online yang selalu terhubung dengan layanan komputasi awan atau Cloud, Komputasi berbasis awan sendiri adalah layanan kompeter yang berbasis Cloud atau berbasis awan yang artinya merupakan gabungan pemanfaatan teknologi komputer dalam suatu jaringan dengan pengembangan berbasis internet (Cloud) yang mempunyai fungsi untuk menjalankan program atau aplikasi melalui komputer - komputer yang terkoneksi pada waktu yang sama secara bersama, tetapi tak semua yang terkonekasi melalui internet menggunakan komputasi awan. Teknologi komputer berbasis sistem Cloud ini merupakan sebuah teknologi yang menjadikan internet sebagai pusat server untuk mengelola data dan juga aplikasi pengguna (Sudarmoyo, 2018). 
Teknologi ini mengizinkan para pengguna untuk menjalankan program tanpa instalasi dan mengizinkan pengguna utuk mengakses data pribadi mereka melalui komputer dengan akses internet, dalam office 365 ada beberapa program berbasis awan yang antara laian adalah: Outlook, One Drive,Word, Exel,Power Point, One Note, Share Point, Teams, Classnote, Sway dan Form.

\section{METODE PENELITIAN}

Penelitian ini dibuat berdasarkan pengalaman lapangan di SMK Muhammadiyah 1 Sukoharjo yang menerapkan aplikasi Microsoft Office 365 dalam pembelajaran daring. Penelitian ini menggunakan metode deskriptif Metode deskriptif adalah prosedur pemecahan masalah yang diselidiki dengan menggambarkan atau melukiskan keadaan subjek atau objek penelitian(seseorang lembaga, masyarakat, dan lain-lain) pada saat berdasarkan fakta-fakta yang tampak sebagaimana adanya. Penelitian ini untuk memberikan gambaran tentang pengaruh aplikasi Microsoft office 365 dalam pembelajaran sejarah di SMK Muhammadiyah 1 Sukoharjo. Teknik pengumpulan data dilakukan dengan pengumpulan berupa Kuesioner tertutup pada kelas X RPL 1. Data yang diperoleh tersebut, kemudian dijabarkan secara deskriptif.

\section{Hasil Penelitian dan Pembahasan Profil Singkat Responden}

Responden dalam penelitian ini adalah siswa kelas X RPL 1 SMK Muhammadiyah 1 Sukoharjo. Adapun jumlah responden sebanyak 30 orang adapun data sebaran responden sebagai berikut.
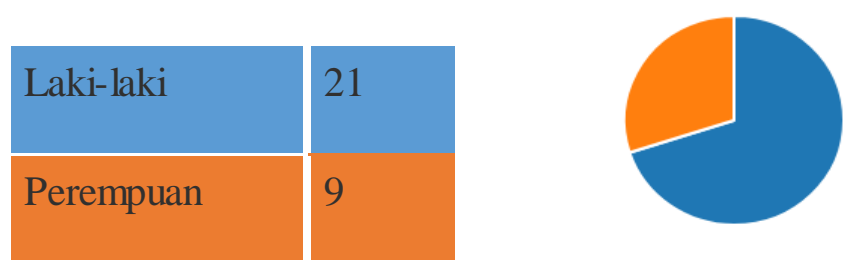

Gambar 1 Sebaran Responden yang Mengisi Kuesioner Penelitian.

Berdasarkan gambar tersebut dapat diketahui bahwa jumlah siswa yang mengisi kuesioner 30 orang yang terdiri dari 21 siswa laki-laki dan 9 siswa perempuan kelas X RPL 1 SMK Muhammadiyah. 
PENGARUH PEMBELAJARAN DARING MATA PELAJARAN SEJARAH MELALUI

MICROSOFT OFFICE 365

(Anisatul Aziizah, Tegar Bima Sakti, Andriyanto)

\section{Kondisi Pembelajaran Online}

Kondisi Pembelajaran Online yang terdiri atas kepercayaan bahwa pembelajar mudah untuk dipahami siswa, dan terdapat sesuatu yang menarik bagi siswa adapun data lengkapnya dapat diliat pada gambar berikut ini.
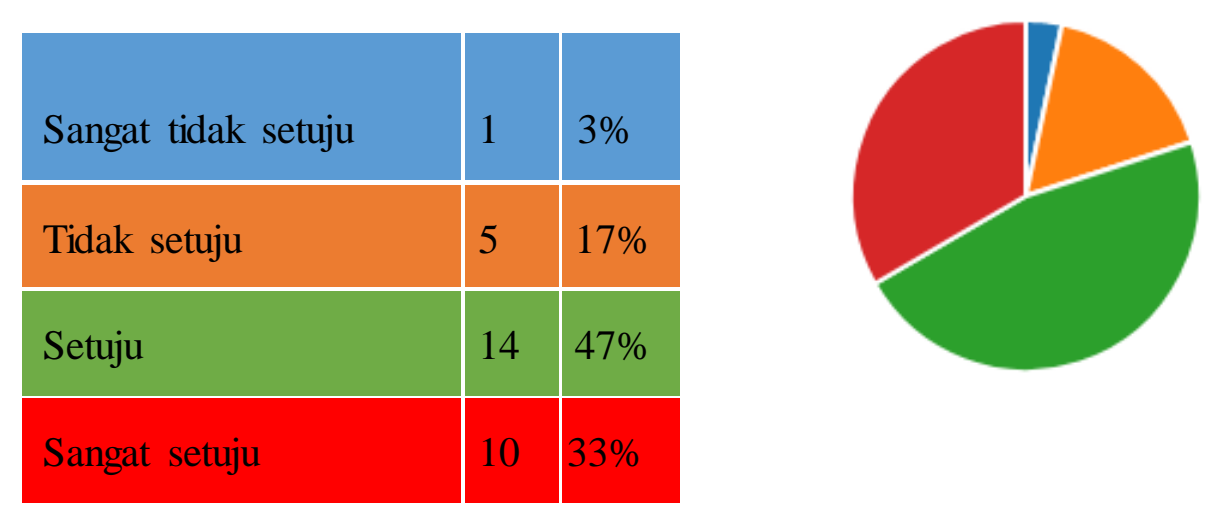

Gambar 2 Pertama kali saya menggunakan pembelajaran online, saya percaya bahwa pembelajaran ini mudah bagi saya.
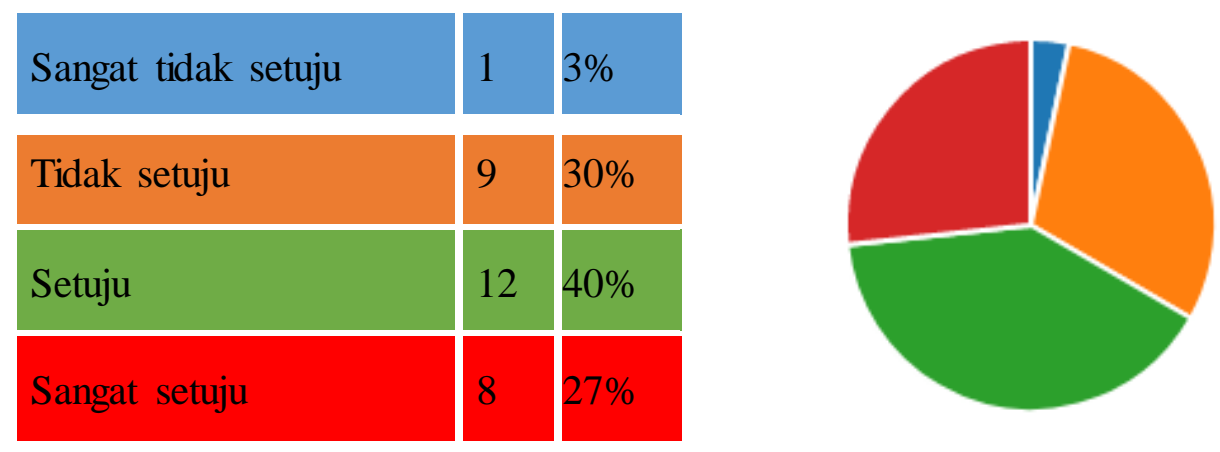

Gambar 3 Pada awal pembelajaran online, terdapat sesuatu yang menarik bagi saya.

Berdasarkan gambar tersebut, diketahui bahwa responden menjawab pertanyaan yang bervariatif. Gambar 2 menjelaskan bahwa sebanyak $47 \%$ siswa setuju dengan adanya pernyataan tersebut dan $33 \%$ siswa setuju dengan pernyataan tersebut. Dilihat dari presentase diatas, maka siswa lebih setuju apabila pembelajaran online dapat dipelajari dengan mudah.

Selanjutnya, pada Gambar 3 menjelaskan bahwa 30\% siswa tidak setuju dengan pernyataan tersebut, $40 \%$ siswa setuju, dan $27 \%$ siswa sangat setuju 
KERATON : Journal of History Education and Culture

Vol. 2, No. 2, Desember 2020

dengan pernyataan tersebut. Dilihat dari presentase diatas, maka siswa mempunyai 3 pendapat yang berbeda. Sebanyak $40 \%$ siswa yang merasakan bahwa pembelajaran online terdpat sesuatu yang tidak menarik.

Materi Pembelajaran Sejarah melalui aplikasi Microsoft Office 365

\begin{tabular}{|l|c|l|}
\hline Sangat tidak setuju & 3 & $10 \%$ \\
\hline Tidak setuju & 8 & $27 \%$ \\
\hline Setuju & 15 & $50 \%$ \\
\hline Sangat setuju & 4 & $13 \%$ \\
\hline
\end{tabular}

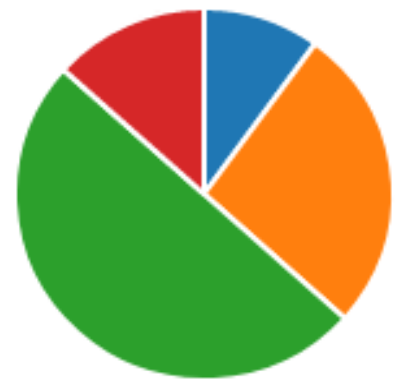

Gambar 4 Materi pembelajaran sejarah melalui aplikasi Microsoft Office 365 lebih sulit dipahami.

\begin{tabular}{|l|l|l|}
\hline Sangat tidak setuju & 0 & $0 \%$ \\
\hline Tidak setuju & 14 & $47 \%$ \\
\hline Setuju & 13 & $43 \%$ \\
\hline Sangat setuju & 3 & $10 \%$ \\
\hline
\end{tabular}

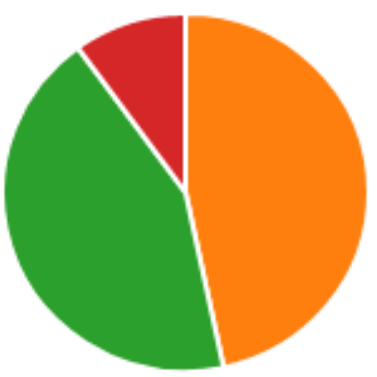

Gambar 5 Materi pembelajaran sejarah melalui aplikasi Microsoft Office 365 sangat menarik perhatian. 


\begin{tabular}{|l|c|l|}
\hline Sangat tidak setuju & 0 & $0 \%$ \\
\hline Tidak setuju & 8 & $27 \%$ \\
\hline Setuju & 18 & $60 \%$ \\
\hline Sangat setuju & 4 & $13 \%$ \\
\hline
\end{tabular}

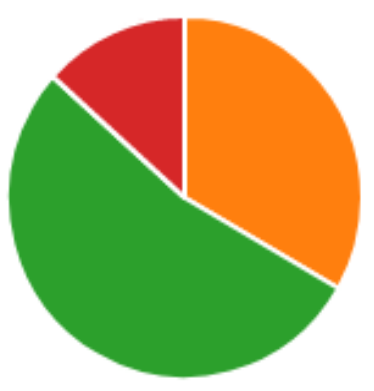

Gambar 6 Saya puas pada pembelajaran sejarah menggunakan aplikasi Microsoft Office 365 sehingga saya ingin mengetahui lebih lanjut pokok bahasan materi sejarah.

\begin{tabular}{|l|l|l|}
\hline Sangat tidak setuju & 0 & $0 \%$ \\
\hline Tidak setuju & 15 & $50 \%$ \\
\hline Setuju & 14 & $47 \%$ \\
\hline Sangat setuju & 1 & $3 \%$ \\
\hline
\end{tabular}

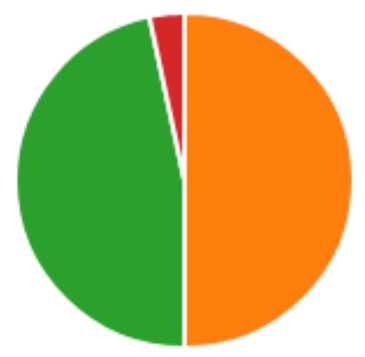

Gambar 7 Isi pembelajaran sejarah menggunakan aplikasi Microsoft Office 365 sulit di pahami.

Berdasarkan Gambar 4, dapat disimpulkan bahwa 10\% siswa sangat tidak setuju dengan pernyataan tersebut, $27 \%$ siswa tidak setuju, $50 \%$ siswa setuju, dan $13 \%$ siswa sangat setuju dengan pernyataan materi pembelajaran sejarah melalui aplikasi Microsoft Office 365 lebih sulit dipahami. Dengan adanya musibah Covid-19, maka pembelajaran dilakukan secara online, dan dibeberapa sekolah memilih aplikasi untuk mendukung pembelajaran. SMK Muhammadiyah 1 Sukoharjo memilih aplikasi Microsoft Office 365 untuk mendukung pembelajaran, namun kendala yang dialami yaitu pemahaman siswa untuk dapat memahami materi lebih sedikit dibandingkan saat pembelajaran tatap muka. Walaupun demikian, pada Gambar 5, aplikasi Microsoft Office 365 untuk pembelajaran sejarah sangat menarik perhatian, dengan adanya data $43 \%$ siswa yang setuju 


\section{KERATON : Journal of History Education and Culture}

Vol. 2, No. 2, Desember 2020

dengan pernyataan tersebut.

Berdasarkan Gambar 6, dapat dilihat bahwa 27\% siswa tidak setuju dengan pernyataan tersebut, $60 \%$ siswa setuju, dan $13 \%$ siswa sangat setuju. Jadi, dapat disimpulkan bahwa lebih banyak siswa yang kurang puas dengan pernyataan pembelajaran sejarah menggunakan aplikasi Microsoft Office 365. Namun, pada Gambar 7, dengan pernyataan isi pembelajaran sejarah menggunakan aplikasi Microsoft Office 365 sulit dipahami, maka dapat dilihat presentase siswa, yaitu $50 \%$ siswa tidak setuju dan $47 \%$ siswa setuju, dan $3 \%$ sangat setuju dengan pernyataan tersebut.

\section{Pengumpulan Tugas Pembelajaran Sejarah}

\begin{tabular}{|l|l|l|}
\hline Sangat tidak setuju & 1 & $3 \%$ \\
\hline Tidak setuju & 8 & $27 \%$ \\
\hline Setuju & 11 & $37 \%$ \\
\hline Sangat setuju & 10 & $33 \%$ \\
\hline
\end{tabular}

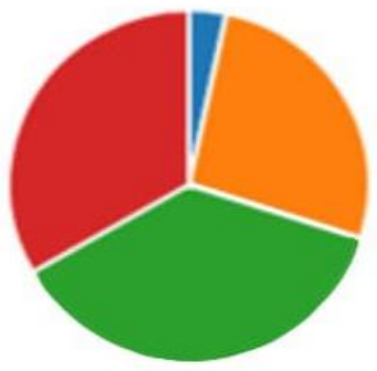

Gambar 8 Tugas-tugas latihan pada pembelajaran sejarah menggunakan aplikasi Microsoft Office 365 terlalu sulit bagi saya.

\begin{tabular}{|l|l|l|}
\hline Sangat tidak setuju & 3 & $10 \%$ \\
\hline Tidak setuju & 7 & $23 \%$ \\
\hline Setuju & 12 & $40 \%$ \\
\hline Sangat setuju & 8 & $27 \%$ \\
\hline
\end{tabular}

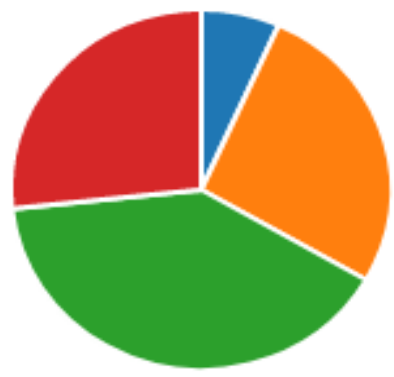

Gambar 9 Saya kurang senang mengirimkan tugas melalui aplikasi Microsoft Office 365. 
Berdasarkan Gambar 8 dan Gambar 9, terdapat pernyataan yang berbeda dan hasil data yang berbeda. Pada Gambar 8, terdapat pernyataan bahwa tugastugas latihan pada pembelajaran sejarah melalui aplikasi Microsoft Office 365 sangat sulit. Dan dapat disimpulkan melalui data kuesioner bahwa, sebanyak 3\% siswa sangat tidak setuju, 27\% siswa tidak setuju, 37\% siswa setuju, dan $33 \%$ siswa sangat setuju dengan pernyataan tersebut. Jadi, lebih banyak siswa yang menganggap bahwa tugas- tugas melalui Microsoft Office 365 sulit.

Selanjutnya, pada Gambar 9, terdapat pernyataan saya lebih senang mengirimkan tugas melalui aplikasi Microsoft Office 365. Dari pernyataan tersebut, terdapat $10 \%$ siswa sangat tidak setuju, $23 \%$ siswa tidak setuju, $40 \%$ siswa setuju, dan $27 \%$ siswa sangat setuju. Jadi, dapat disimpulkan bahwa siswa kurang senang apabila penugasan sejarah melalui Microsoft Office 365.

\section{Isi Pembelajaran Sejarah Melalui Microsoft Office 365}
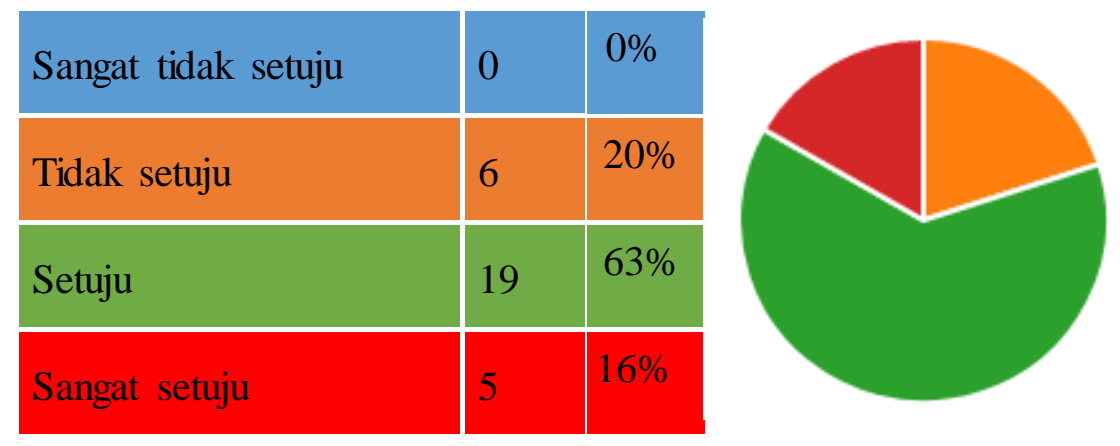

Gambar 10 Isi pembelajaran sejarah menggunakan aplikasi

Microsoft Office 365 bermanfaat bagi saya.
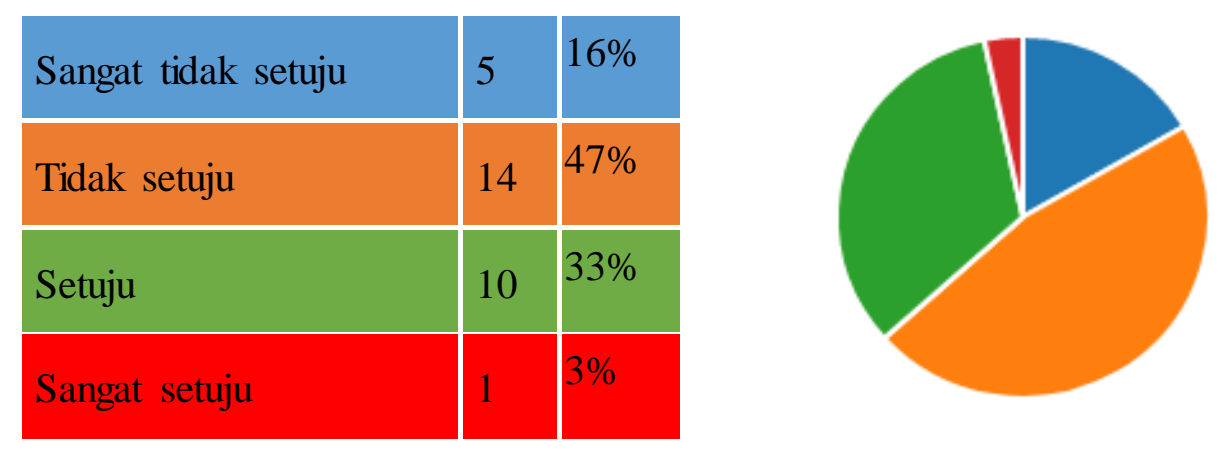

Gambar 11 Sedikitpun saya tidak memahami isi pembelajaran sejarah menggunakan aplikasi Microsoft Office 365. 

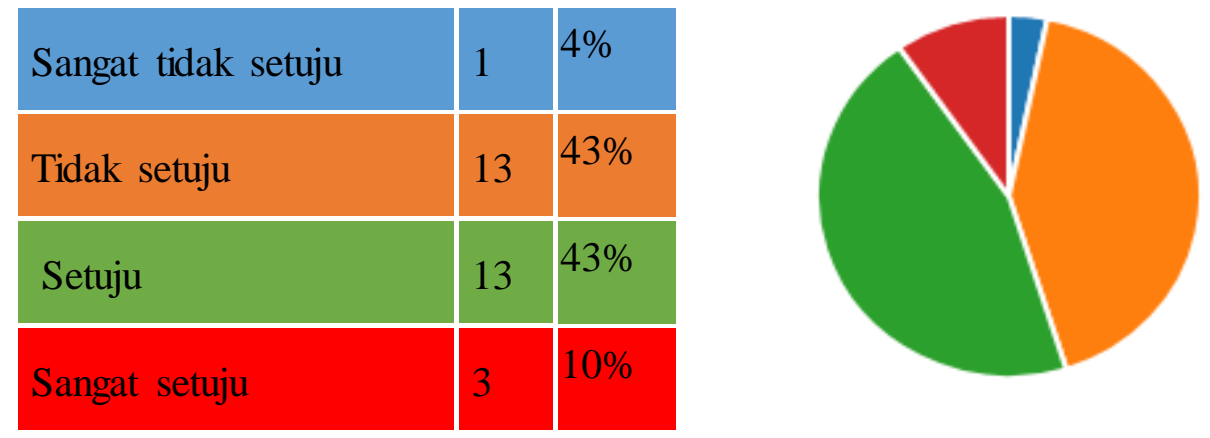

Gambar 12 Saya setuju apabila aplikasi Microsoft Office 365 digunakan dalam proses pembelajaran mata pelajaran sejarah saat ini.

Gambar 10 dan Gambar 11 merupakan pernyataan yang berbeda. Pada gambar 10 terdapat pernyataan isi pembelajaran sejarah melalui aplikasi Microsoft Office 365 bermanfaat bagi saya. Dapat dilihat dari data kuesioner, sebanyak 20\% siswa tidak setuju dan $63 \%$ siswa setuju dengan pernyataan tersebut. Jadi, kesimpulan dari pernyataan tersebut, siswa menganggap bahwa pembelajaran sejarah melalui Microsoft Office 365 bermanfaat bagi siswa. Sedangkan pada Gambar 11, terdapat pernyataan sedikitpun saya tidak memahami isi pembelajaran sejarah menggunakan aplikasi Microsoft Office 365. Dari pernyataan tersebut, 3\% siswa sangat tidak setuju, $47 \%$ siswa tidak setuju, dan $33 \%$ siswa setuju. Melalui data diatas, dapat disimpulkan bahwa lebih banyak siswa dapat memahami isi pembelajaran sejarah menggunakan aplikasi Microsoft Office 365.

Pada Gambar 12, menampilkan pernyataan saya setuju apabila aplikasi Microsoft Office 365 digunakan dalam proses pembelajaran mata pelajaran sejarah saat ini. Data kuesioner menunjukkan bahwa $43 \%$ siswa tidak setuju, $43 \%$ siswa setuju, dan $10 \%$ siswa sangat setuju pada pernyataan tersebut. Kesimpulannya bahwa hasil menunjukan pembelajaran sejarah lewat aplikasi Microsoft Office 365 berimbang, antara siswa yang tidak setuju dengan siswa yang setuju. 


\section{Kondisi Ekstemal Dalam Pembelajaran Daring}
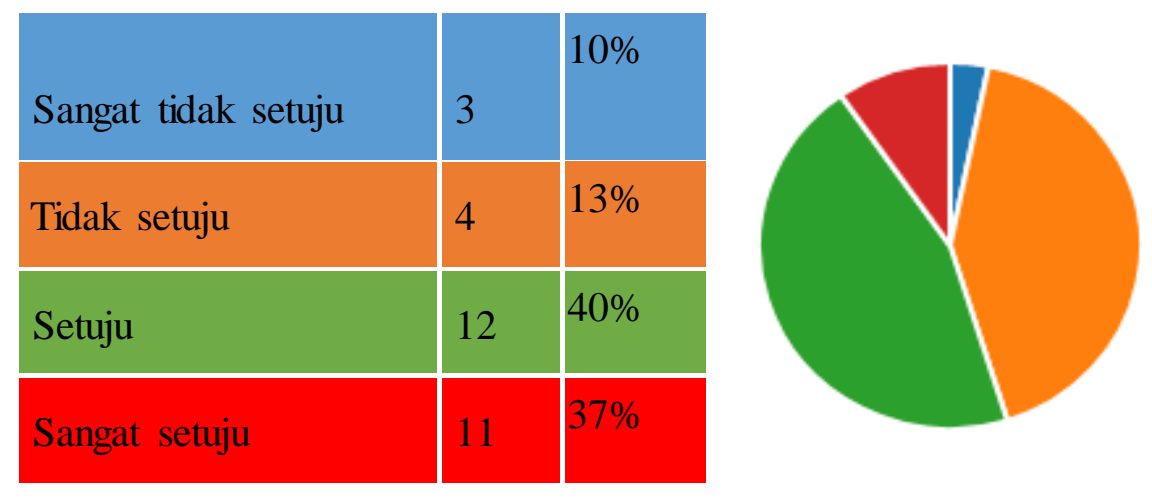

Gambar 13 Orang tua saya sangat peduli dengan pendidikan saya

\begin{tabular}{|l|l|l|}
\hline Sangat tidak setuju & 3 & $10 \%$ \\
\hline Tidak setuju & 9 & $30 \%$ \\
\hline Setuju & 14 & $47 \%$ \\
\hline Sangat setuju & 4 & $13 \%$ \\
\hline
\end{tabular}

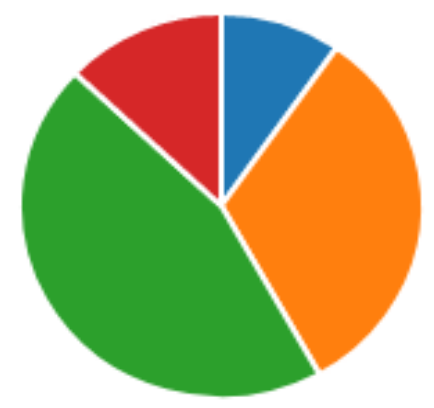

Gambar 14 Orang tua saya memantau proses pembelajaran sejarah melalui Microsoft Office 365.

\begin{tabular}{|l|l|l|}
\hline Sangat tidak setuju & 1 & $3 \%$ \\
\hline Tidak setuju & 7 & $24 \%$ \\
\hline Setuju & 19 & $63 \%$ \\
\hline Sangat setuju & 3 & $10 \%$ \\
\hline
\end{tabular}

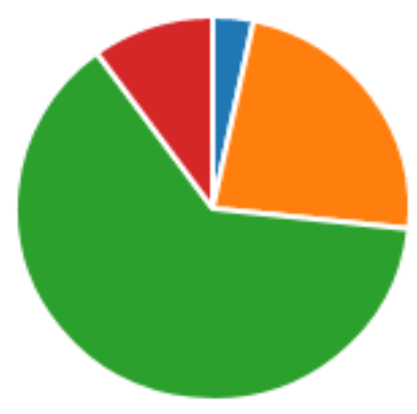

Gambar 15 Guru mata pelajaran selalu memantau saya dalam proses pembelajaran sejarah melalui aplikasi Microsoft Office 365. 
Gambar 13 terdapat pernyataan yang menyatakan bahwa orang tua saya sangat peduli dengan pendidikan saya, diperoleh $40 \%$ siswa setuju, dan sebanyak $37 \%$ siswa menyatakan sangat setuju dengan pernyataan tersebut. Jadi, dari pernyataan tersebut dapat disimpulkan bahwa orang tua siswa seluruhnya sangat peduli dengan pendidikan anaknya.

Selanjutnya, untuk gambar 14 yang menyatakan bahwa orang tua saya memantau proses pembelajaran sejarah melalui Microsoft Office 365, dilihat dari data kuesioner tersebut menunjukkan sebanyak $10 \%$ siswa sangat tidak setuju, $30 \%$ siswa tidak setuju, $47 \%$ siswa setuju, dan $13 \%$ siswa sangat setuju. Maka dapat disimpulkan bahwa tidak semua orang tua siswa memantau anaknya dalam proses pembelajaran sejarah melalui Microsoft Office 365, namun tetap sebagian besar dari orang tua siswa tersebut memantau proses pembelajaran sejarah melalui Microsoft Office 365. Dan pada gambar 15, terdapat pernyataan guru mata pembelajaran selalu memantau saya dalam proses pembelajaran sejarah melalui aplikasi Microsoft Office 365, hasil data kuesioner menunjukkan sebesar $24 \%$ siswa tidak setuju, $63 \%$ siswa setuju, dan $10 \%$ siswa sangat setuju dengan pernyataan tersebut. Jadi, kesimpulannya adalah tidak semua siswa menyetujui pernyataan tersebut, terdapat sebagian kecil siswa yang tidak menyetujuinya dan selainnya setuju dan sangat setuju akan adanya pernyataan tersebut.

\section{Penghambat Pelajaran Sejarah Melalui Microsoft Office 365}
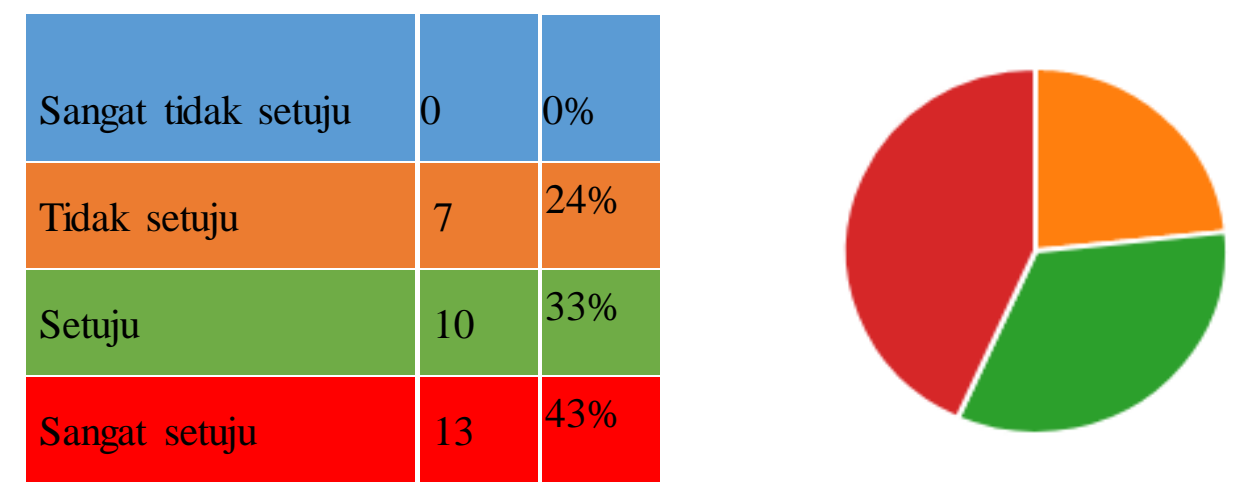

Gambar 16 Signal dalam Smartphone sebagai penghambat saya saat proses pembelajaran sejarah menggunakan aplikasi Microsoft Office 365. 
Gambar 16 yang menyatakan bahwa signal dalam smartphone sebagai penghambat saya saat proses pembelajaran sejarah menggunakan aplikasi Microsoft Office 365, dilihat dari kuesioner tersebut bahwa sebesar $43 \%$ siswa tidak setuju, 24\% siswa setuju dengan pernyataan tersebut. Maka didapatkan kesimpulan bahwa seluruh siswa merasakan hal yang sama yaitu signal dalam smartphone sebagai penghambat saat proses pembelajaran sejarah menggunakan aplikasi Microsoft Office 365.
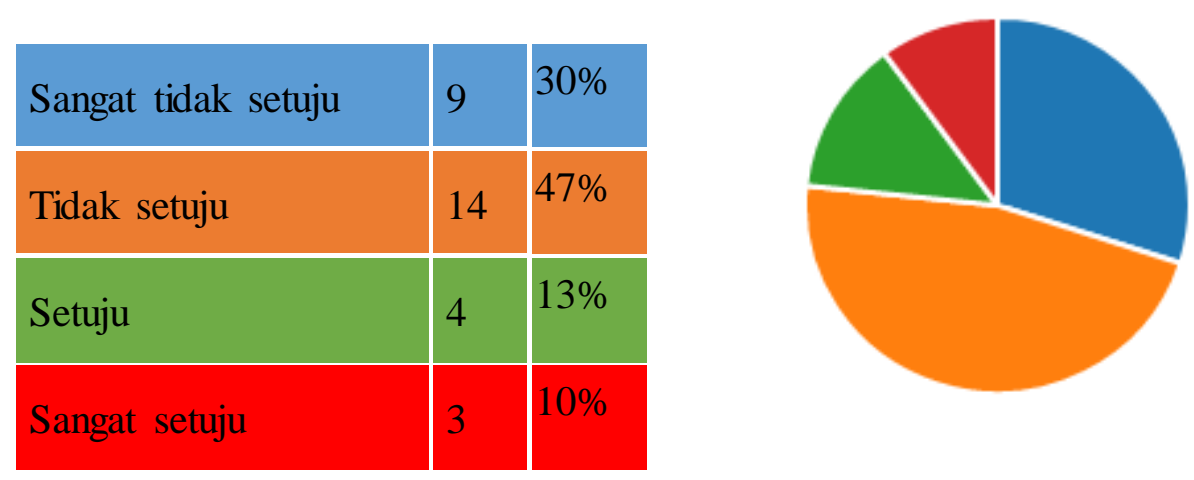

Gambar 17 Microsoft Office 365 mudah diakses

Gambar 17 menyatakan bahwa 30\% siswa sangat tidak setuju, 47\% siswa tidak setuju dengan pernyataan tersebut dapat disimpulkan bahwa siswa sulit mengakses Microsoft Office 365.

\begin{tabular}{|l|l|l|}
\hline Sangat tidak setuju & 6 & $20 \%$ \\
\hline Tidak setuju & 15 & $50 \%$ \\
\hline Setuju & 8 & $27 \%$ \\
\hline Sangat setuju & 1 & $3 \%$ \\
\hline
\end{tabular}

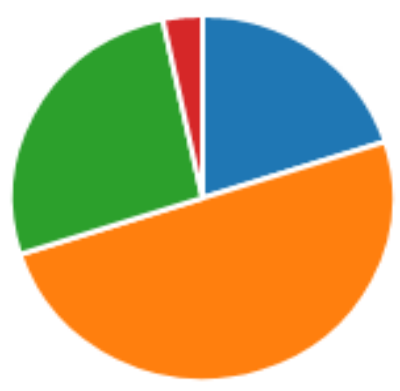

Gambar 18 Cara guru menyampaikan materi sejarah melalui Microsoft Office 365 sangat menyenangkan.

Gambar 18 menyatakan bahwa cara guru menyampaikan materi sejarah melalui aplikasi Microsoft Office 365 sangat menyenangkan, didapat sebesar $50 \%$ siswa tidak setuju, $27 \%$ siswa setuju, dan $3 \%$ siswa sangat setuju dengan 
pernyataan tersebut. Maka kesimpulan yang di dapatkan dari kuesioner tersebut adalah sebagian besar siswa tidak menyetujui adanya pernyataan tersebut.

\section{SIMPULAN DAN SARAN}

Pembelajaran dengan menggunakan sistem daring menjadi bahasan yang menarik dalam masa pandemi Wabah Covid-19 ini. Merujuk pada hasil analisis data melalui kuesioner, dapat disimpulkan bahwa siswa kelas X RPL 1 SMK Muhammadiyah 1 Sukoharjo Tahun Ajaran 2020/2021 memiliki kendaladalam proses pembelajaran melalui aplikasi Microsoft Office 365. Tidak sedikit siswa yang tidak setuju dengan pembelajaran daring melalui aplikasi Microsoft Office 365 , kendala kendala yang di alami siswa beragam dari masalah teknis yaitu. Prihal kendala jaringan di setiap siswa yang berbeda dari $76 \%$ siswa merasa jaringan adalah kendala utama dalam pembelajaran daring menggunakan aplikasi Microsoft Office 365 serta aplikasi yang terlalu besar penyimpanan ruangnya membuat aplikasi ini hanya bisa di akses melalui laptop ataupun PC. Ada pula kendala dalam penyampaian materi yaitu kesulitan siswa dalam pemahaman materi yang di berikan guru. Serta siswa kesulitan dalam pengumpulan tugas. Walaupun demikian, Dengan berbagai fitur dalam satu aplikasi semakin memudahkan guru untuk menggunakannya, karena guru dapat menyampaikan bahan ajar dengan menggunakan berbagai fasilitas atau fitur yang disediakan oleh office, tidak hanya berupa teks tetapi bisa dalam bentuk teks. bentuk video. Selain itu, pengajar juga dapat memantau keaktifan siswanya dengan fitur chat, dan dapat secara efisien memberikan tugas sebagai bahan evaluasi untuk mengetahui tingkat pemahaman siswa. Selain itu, Microsoft Office 365 juga dapat digunakan untuk konferensi video untuk pembelajaran tatap muka melalui online.

Dari beberapa pegaruh yang ditemukan, peneliti memberikan saran untuk pembelajaran daring agar dapat dilaksanakan lebih maksimal, adapun saran sebagai berikut :

1. Guru sebaiknya mencoba menggunakan aplikasi lain. Agar proses pembelajaran bisa maksimal dilakukan. Walaupun fitur dari Microsoft Office 365 lengkap tapi dari siswa merasa kesulitanmengaksesnya. 
2. Guru sebaiknya membuat modifikasi materi disetiap pertemuan agar dari siswa tidak merasa jenuh dengan model pembelajaran daring.

3. Sarana dan prasarana yang lengkap meliputi perpustakaan dan jaringan internet perlu diperhatikan untuk memaksimalkan jelajah pustaka yang dilakukan siswa. Hal ini dapat dilakukan dengan menerapkan protokol kesehatan yang berlaku pada kondisi saat ini.

4. Siswa harus mempunyai pemikiran yang positif terhadap pembelajaran sejarah melalui aplikasi Microsoft Office 365.

Dengan menggunakan aplikasi Microsoft Office 365 dalam proses pembelajaran sejarah, maka diharapkan agar memberikan dampak positif pada kualitas pembelajaran mata pelajaran sejarah. Siswa juga diharapkan dapat memaksimalkan penggunaan Microsoft Office 365 dalam pembelajaran sehingga dapat meningkatkan pemahaman siswa dalam proses pembelajaran sejarah.

\section{DAFTAR PUSTAKA}

Asih, Shintya Gugah. 2020. Pendidikan Era Revolusi Industri 4.0 di Tengah Covid-19 (Online). (https $/ /$ ombudsman. go.id/artikel/r/artikel- pendidikanera-revolusi-indus tri-40-di- tengah-covid-19

Bilfaqih, Y., \& Qamaruddin. M.N.,(2015). Esensi Pengembangan Pembelajaran Daring, Deepublish.

Ezalia, E., R, I. E., Elizabeth, G., My, W. A. N. H., Norhanim, A., Wahidah, A., Ym, C., Rahimah, A., Chin, J. G., Juliana, I., Hamid, A., Gunasagaran, K., Amir, J., John, P., Azmi, A., Mangantig, E., Hockham, C., Ekwattanakit, S., Bhatt, S., ... Mary Anne Tan, J.-A. (2020). No

主観的健康感を中心とした在宅高齢者における 健康関連指標に関する共分散構造分析Title. Orphanet Journal of Rare Diseases, 21(1), 1-9. https://doi.org/10.1155/2010/706872

Imania, K. A., \& Bariah, S. K. (2019). Rancangan Pengembangan Instrumen Penilaian Pembelajaran Berbasis Daring. Jurnal Petik, 5(1), 31-47. https://doi.org/10.31980/jpetik.v5i1.445 
Kuntarto, E. (2017). Keefektifan Model Pembelajaran Daring Dalam Perkuliahan Bahasa Indonesia di Perguruan tinggi. Journal Indonesian Language Education and Literature, 3(1), 53-65. http://www.syekhnurjati.ac.id/jurnal/index.php/jeill/\%0APEMBELAJARA $\mathrm{N}$

Kusumaningsih, D., \& Press, U. B. (2011). Strategi pembelajaran bahasa indonesia.

M. Basyiruddin Usman, Media Pembelajaran, (Jakarta: Ciputat pers, 2002), hlm.1., Yogyakarta.

Panduan Penggunaan Aplikasi Microsoft Teams MICROSOFT TEAMS PLATFORM. (n.d.).

Priansa, D. 2017. Pengembangan Strategi \& Model Pembelajaran. Penerbit PUSTAKA SETIA. Bandung.

Sudarmoyo. (2018). Pemanfaatan aplikasi sway untuk media pembelajaran. Jurnal Pendidikan Dan Pembelajaran, Vol 3 No 4 (2018, 3(4). 